\title{
Development and Performance Evaluation of a Two-Wheel Tractor Mounted Conservation Tillage Trencher for Sugarcane
}

S. S. Tabriz ${ }^{1,2}$, M. A. Awal ${ }^{2}$, M. A. Kader ${ }^{*}$, M. S. Hossen ${ }^{1}$, Md. Rostom Ali², Md. Ayub Hossain ${ }^{4}$

${ }^{1}$ Agricultural Engineering Division, Bangladesh Sugarcrop Research Institute, Ishurdi, Pabna-6620, Bangladesh.

${ }^{2}$ Department of Farm Power and Machinery, Bangladesh Agricultural University, Mymensingh-2202, Bangladesh.

${ }^{3}$ Centre for irrigation and water management, Rural Development Academy (RDA), Bogura-5842, Bangladesh.

${ }^{4}$ FMP Engineering Division, Bangladesh Agricultural Research Institute, Joydebpur, Gazipur-1701, Bangladesh.

*Corresponding author: kader@rda.gov.bd (Mohammad Abdul Kader); OCRID ID: 0000-0003-32461963. Tel.: +88-01773186944. 


\begin{abstract}
An efficient design of conservation tillage trencher (CTT) saves time, natural resources, and conserves soil health by avoiding vigorous soil disturbance of tillage operations. A two-wheel tractor operated CTT has constructed with modified rotary shafts, toolbar frames, depth control bars, bed shapers and chisel ploughs for conservation tillage operation of sugarcane plantation. The performance evaluation of developed CTT was tested for comparing the suitability with small-scale farmer's practice (SFP) and large farm practice (LFP). Finally, the CTT is applied for preparing sugarcane farmland in different conservation tillage methods of i) bed cum trenching (BT), ii) zero-tillage trenching (ZT) and iii) strip-tillage (ST). The performance of effective field capacities of CTT were $0.14 \mathrm{ha} \mathrm{h}^{-1}, 0.12 \mathrm{ha} \mathrm{h}^{-1}$ and $0.14 \mathrm{ha} \mathrm{h}^{-1}$ for BT, ZT and ST, respectively. Developed CTT saved time $80 \%$ and $26-37 \%$ over SFP and LFP, and required $96 \%$ and 26-36\% less labour than SFP and LFP, respectively. Conservation tillage required 7-10 1 ha $^{-1}$ diesel whereas SFP and LFP required $251 \mathrm{ha}^{-1}$ and $651 \mathrm{ha}^{-1}$, which reduced $\mathrm{CO}_{2}$ emission by $60-72 \%$ and $85-89 \%$ compared to SFP and LFP, respectively. Ultimately, newly developed CTT saved sugarcane land preparation costs by $86 \%$ to $90 \%$ compared to conventional tillage systems.
\end{abstract}

Key words: Tillage; trencher; sugarcane plantation; energy consumption; conservation agriculture. 


\section{Introduction}

Sugarcane (saccharum spp.) is an important cash crop, and only source of white sugar in Bangladesh [1] and sugarcane cultivation occupies only $0.87 \%$ agricultural land of the country [2]. However, with the increasing demand for sugar due to population growth, where domestic sugarcane satisfies only $25 \%$ of national demand [3]. Natural resource saving, profitable and climate-smart, farm innovations are essential in every step of sugarcane farming to increase and maintain a sustainable production in the country as well as to reduce shortage of national demand. Tillage operation is most important for crop establishment as well as an expensive component in farm activities that plays a vital role in sustainable sugarcane farming. Tillage is involving with mechanical soil disturbance aiming for crop production [4] that makes planting easier, control weeds, pests and diseases [5]. Land preparation through intensive tillage is a common component of conventional system of commercial sugarcane farming which increases cost of production. In contrast, land preparation is the second most costly component that comprises $21 \%$ of total production cost where harvesting and loading of cane rank first (35\%) [6]. Conventional tillage practices for crop production in Bangladesh are highly resourced expensive in terms of cost, time, labour and fuel for tilling land [7-9. In contrast, two types of tillage operations carried out in Bangladesh during sugarcane land preparation that are small farmer's practice (SFP) and large farm practice (LFP) $[1,10]$. SFP is based on two-wheel tractor and manual human labour whereas LFP is based on four-wheel tractor mounted tillage implements. SFP is highly labour intensive, time consuming and costly where LFP requires large and costly machinery which are beyond the capacity of small-scale farmers. Therefore, once farm authorities supported tractor-mounted tillage implements at farmer's field in the mill zone area under a mechanized sugarcane cultivation program of Bangladesh Sugar and Food Industries Corporation (BSFIC) that covered about $10 \%$ of sugarcane fields $[11,12]$. Unfortunately, that program has failed due to some mismanagement of social conflict, and lack of proper management between farmers and mill authority. As a result, still now small-scale sugarcane farmers are in trouble for land preparation due to the lack of suitable tillage implements. Moreover, conventional tillage practices are not cooperative to resource saving and climate smart tillage options since it involving with vigorous tillage. Instead of soil conservation excessive mechanical disturbance of soil through tillage is responsible for soil degradation and yield declines of sugarcane farm land $[1,13]$. So, finding of appropriate conservation tillage implements is a great challenge for SFP to meet their necessary demand of sugarcane land preparation.

Conservation tillage boosts sustainable and profitable sugarcane farming [14, 15]. Conservation agriculture (CA) has been proved beneficial significantly in terms of crop yield, water use efficiency, net economic return and global warming contributing to the Sustainable Development Goals in South Asia [16]. Moreover, conservation tillage is the first and essential component among the three main components of 
CA. It plays an important role to increase organic carbon in the soil of sugarcane farms [17] and limits Greenhouse gas (GHG) emission across conventional mechanized tillage system. Moreover, conservation tillage in sugarcane farming reduces substantial cost savings and improves soil productivity [18-20]. Twowheeled tractors are very popular for land preparation in smallholder farming systems in South and East Asia including Bangladesh [21]. Farmers of Bangladesh has accepted 2-wheel tractor operated CA machinery and local manufacturers fabricated machinery [22]. However, these CA machineries are suitable for cereal, pulse and maize crops but not for sugarcane because sugarcane setts or settlings are not similar in size and shape to those seeds [1]. Sugarcane setts/seedlings is planted in trenches or furrows by the manual laborer. Therefore, to overcome the limitations, design of 2-wheel tractor mounted conservation tillage implement is crucial to make trenches for successful sugarcane establishment with less mechanical disturbance of soil, which can be defined as conservation tillage trencher (CTT) for sugarcane plantation.

A range of farm machinery types have been developed in Bangladesh for CA, with research indicating the potential for production cost savings, improved water use efficiency, reduced irrigation requirements, and improved soil quality with environmental benefits, among others [21]. CTT may provide less soil disturbance and optimum depth of trench instead of excessive tillage which will reduce machine energy consumption and labour involvement of trenching during sugarcane plantation. Thus, a CTT can serve the present demand of tillage implement and overcome demerits of excessive tillage in sugarcane farming. Moreover, improved agricultural implement and machineries are essential to uplift farm mechanization for increasing agricultural productivity [23]. Therefore, a modification of rotary shaft (blade arrangement) and attachment of some components as chisel plough, bed shaper can be fabricated in a two-wheel tractor mounted conservation tillage trencher which may provide flexibility of tillage operations in sugarcane farming especially for preparing raised bed cum trench, zero-till trench and strip tillage. Also, modification of rotary shaft of power tiller through reducing total number of blades as well as rearranging of blades is important for favorable seedbed preparation with a single pass of tillage operation and evading unnecessary tillage between two furrows of sugarcane plantation. Bed shaper is for control placement of soil that troughed by blades for making improve the architecture of bed cum trench and chisel plough can optimize depth and width of furrow. Therefore, improved design of farm implement can ensure timeliness and ecofriendliness of operation, cost-effectiveness and reduce drudgery of farm operations.

Appropriate design and performance evaluation of the CTT as a part of improved tillage implement for crop establishment in sugarcane farmland are necessary in Bangladesh. The design of a tillage implement has a significant influence on the performance of the machine. In the study, a PT operated CTT will be designed and fabricated locally for performance evaluation in the field. Moreover, few common performance indicators as furrow spacing, depth and width of furrow, forward speed, effective width and 
field capacity will be considered to evaluate the developed CTT with a suitable soil condition for sugarcane crop establishment. Finally, performances of CTT in terms of resource saving as fuel, time, labour and environmental aspects will be compared over the conventional machine used in land preparation practice in sugarcane farming.

\section{Material and methods}

\subsection{Conceptual of conventional tillage for sugarcane}

Different tillage options for land preparation in sugarcane farming can be conceptualized as conventional tillage and conservation tillage in Figure 1. Existing tillage practice for sugarcane plantation is intensified with the advent of mechanical power of two-wheel or four-wheel tractor that ensures excessive tillage and deep planting in a row. Two types of conventional tillage operations carried out in Bangladesh during sugarcane land preparation. SFP involves multiple passes (three to five) of two-wheel tractor for lump braking, levelling as well as loosen the soil adequately and then dig trenches manually (Figure 1(a)). In addition, three types of four-wheel tractor-mounted tillage implements are used in LFP which are limited to institutional and industrial sugarcane farms for planting canes as follows: i) one pass of disc plough, ii) two to three passes of disc harrow, and iii) finally, one pass of trencher (Figure 1(b)). One pass of tractor mounted disc plough inverts upper layer of soil that provides deep tillage. Multiple passes (two to three) of tractor-mounted disc harrow is carried out after disc ploughing for lump braking, levelling and smoothing the soil surface adequately. After completion of harrowing trench is prepared by a single pass of tractor mounted trencher. Thus, multiple activities of conventional land preparation practices responsible for increasing cost of production with less net return.

\subsection{Conservation tillage concept of sugarcane}

Considering principles of conservation tillage, we proposed three different tillage options for sugarcane as bed cum trenching, zero-tillage trenching and strip tillage.

(i) Bed cum trenching (BT): Bed cum trenching provides minimum tillage in sugarcane that makes bed and trench at a time. It can consider as prior loosening of the soil only along the line of trench and removal of that tilled soil to make bed and trench. It may necessary for sugarcane sett or seedlings and fertilizer placement in the soil. It requires a tillage implement having two main functional components as: a) tilling of soil along the line as well as lateral throwing of that tilled soil to make bed and trench and $b$ ) optimization of trench depth through chiseling (Figure 1(c)). 
(ii) Zero-tillage trenching (ZT): ZT method for plant establishment that consists only the opening of a narrow strip or small hole in the ground for seed placement [24]. ZT trenching for sugarcane will conceive as only chiseling of soil for sugarcane sett or seedlings and fertilizer placement. This tillage option ensures less disturbance of soil than BT (Figure 1(d)).

(iii) Strip tillage (ST): ST can introduce in sugarcane farming as conservation tillage that forms a strip seedling zone for seed germination or seedlings establishment and can be done by mechanical disturbance of soil in a row where space between two rows remains undisturbed [24] (Figure 1(e)).

\subsection{Fabrication of conservation tillage trencher for sugarcane}

A two-wheel tractor operated conservation tillage trencher (CTT) for sugarcane was designed and fabricated in the workshop of Bangladesh Sugarcrop Research Institute (BSRI), Pabna, Bangladesh. Operating performance and efficiency of developed CTT was evaluated through field test at BSRI demonstration farm. In the study, three conservation tillage options (BT, ZT and ST) for sugarcane farming were considered for evaluating developed CTT. Details of implement development and field experiment are described as below.

\subsubsection{Design consideration of CTT}

Factors considered for CTT design were i) local manufacturers can easily fabricate, ii) low cost of fabrication so that small and medium farmers or service provider can purchase easily, iii) easy to operate by a single operator, iv) easy to repair and maintenance with low-cost involvement and v) easy transportation from one place to another place.

\subsubsection{Fabrication of CTT}

The two-wheel tractor mounted CTT was fabricated using mild steel (MS) materials considering low cost and availability in local markets as MS angle, solid bar, MS sheet, ball bearing, and nut-bolts. The main functional parts of CTT were modified rotary shaft, toolbar frame, depth control bar, bed shaper roller and two chisel Ploughs (Figure 8). The CTT was attached by 2 -wheel power tiller with power consumption between 9-12 kW.

\subsubsection{Modified rotary shaft}

Number of pockets for blades setting in the rotor have rearranged and " $L$ " shaped blades were used for bed cum trenching and strip tillage. However, total numbers of blades used during different conservation tillage operations have reduced for minimum disturbance of soil. Six numbers of blades were set along two 
perimeters at each end of the rotary shaft having inward facing for bed cum trenching (Figure 2 (a)). That will cut as well as through the soil back having an inward direction. In addition, 6 numbers of blades were set along two perimeters as well as at middle portion of rotor having inward facing during strip tillage (Figure 2 (b)) and no blade was used during zero-tillage trenching.

\subsubsection{Bed shaper roller}

A special type roller was fabricated at BSRI workshop using $1 \mathrm{~mm}$ thick MS sheet and two conical structures with outward large facing at both end edge (Figure 3). Inner distance between two conical shaped structures of the roller confirms the width of bed since those conical shaped structure increases the inward movement of the back throw soil by the rotor and inner part of the roller press the soil that make bed.

\subsubsection{Two chisel Ploughs}

The basic functions of chisel ploughs involve increasing depth of trench to make it suitable for sugarcane plantation. Two small size chisel ploughs were fabricated using $5 \mathrm{~mm}$ thick MS plate/MS Flat bar at Agricultural Engineering Workshop of BSRI and that were placed behind the roller with a frame using the holder. Distance between two chisel ploughs and vertical movement of those ploughs can adjust through positioning of trenchers using chisel ploughs holders.

\subsubsection{Chisel plough}

Soil failure pattern by a narrow cutting blade can describe as the failure wedge ahead of the blade consists of the center wedge, two side crescents and straight rupture plane at the bottom as shown in Figure 4 [25, 26]. According to this soil failure pattern, force acting on a narrow cutting blade depends on rake angle of the cutting blade $(\alpha)$, angle of soil failure plane $(\beta)$ and rupture distance $(r)$ where rake angle $(\alpha)$ is the geometric parameter of the tillage tool (Figure 4). Hence, the efficiency of a chisel plough directly depends on the rake angle of the chisel plough. The draft force decreased with the rake angle and reached its minimum value at $45^{\circ}$ rake angle [27]. Hence, $45^{\circ}$ rake angle has chosen for our developed chisel plough. Besides that, length of the trencher $\left(L_{\mathrm{C}}\right)$ will depend on depth of plantation. Sugarcane plantation at a depth of 100-150 mm is enough for crop establishment and production [10, 28]. Since for a desired depth, $d=150$ $\mathrm{mm}$, length of trencher (chisel plough or narrow blade) will be $\mathrm{L}_{\mathrm{C}}=212 \mathrm{~mm}$ or more as $220 \mathrm{~mm}$ (Figure 5(a) and 5(b)) and equation (1).

$$
L_{c}=\frac{d}{\sin \theta}=\frac{150 \mathrm{~mm}}{\sin 45^{\circ}}=212 \mathrm{~mm}
$$


Usually, maximum diameter of sugarcane is less than $50 \mathrm{~mm}$ so, width of the trencher was taken as $50 \mathrm{~mm}$. Due to side crescents width of the trench will be more than $50 \mathrm{~mm}$ that is enough for insertion of sugarcane set or seedlings.

\subsubsection{Toolbar frame}

The toolbar frame was fabricated using locally available mild steel materials (Figure 6) to mount chisel ploughs and bed shaper roller. Some solid mass was removed from $113 \mathrm{~cm}$ long trencher mounting structure of toolbar frame to reduce the weight of the implement (Figure 6) so that operator can easily turn out during operation. Toolbar frame and bed shaper roller are attached behind the rotor using a flat bar and two depth control bars.

\subsubsection{Depth control bar}

Two $5 \mathrm{~mm}$ thick, $50 \mathrm{~mm}$ wide and $300 \mathrm{~mm}$ long MS flat bar having 14 numbers of holes that were attached with toolbar frame (Figure 6) to lift and down the bed shaper roller and toolbar frame to control depth of tillage.

\subsubsection{Chisel ploughs holder}

Two clamps as chisel ploughs holder (Figure 7) were used to attach the chisel Ploughs with chisel ploughs mounting structure of toolbar frame.

\subsection{Evaluation of field performance}

The field performance of developed CTT machine was tested in the BSRI farm for determining implements forward speed, effective soil cutting width, turning time and field capacity. The experiment site is located at $24^{\circ} 8^{\prime}$ North latitude and $89^{\circ} 4^{\prime}$ East longitude with an elevation of $15.5 \mathrm{~m}$ above the mean sea level. The soil of experimental field was a silt loam, which contains $21 \%$ sand, $57 \%$ silt and $22 \%$ clay. During field test, the moisture content of the soil was $17 \%$, average soil penetration resistance was $1.25 \mathrm{~kg} \mathrm{~cm}^{-2}$ and bulk density was $1.45 \mathrm{~g} \mathrm{cc}^{-1}$ at $0-150 \mathrm{~mm}$ depths. The developed CTT implement was compared with two conventional land preparation methods in terms of fuel consumption, energy requirement, $\mathrm{CO}_{2}$ emission for fuel consumption, time and labour requirement for sugarcane land preparations. Conventional methods of land preparation for sugarcane are four-wheel tractor base land preparation (single pass of disc plough + 2 passes of disc harrow + single pass of tractor trencher) and two-wheel tractor base land preparation (4 passes of two wheel tractor + manual trenching using spade). Each type of method was tested on three different fields with size of $40 \mathrm{~m} \times 27 \mathrm{~m}$. For accuracy of results, each type of method was tested three 
repeated times and data was collected. Prepared lands were also evaluated in terms of depth and width of trench. Finally, cost of land preparation for each method was calculated for economic analysis.

Necessary data were recorded from field test and equations as described below were used to calculate different performance indicators as stated above. Forward speed of the machine can be calculated following [29].

$$
S=\frac{3.6 d}{t}
$$

where, $\mathrm{d}=$ distance traveled $(\mathrm{m}), \mathrm{t}=$ travel time $(\mathrm{s})$ and $\mathrm{S}=$ forward speed $\left(\mathrm{km} \mathrm{h}^{-1}\right)$. Effective field capacity (EFC) is the actual area coved by the machine within unit time [30].

$$
\text { Effective field capacity }=\frac{\mathrm{A}}{\mathrm{T}}
$$

Where, EFC is ha $\mathrm{h}^{-1}, \mathrm{~A}=$ area covered by the machine (ha) and $\mathrm{T}=$ Total time required to cover the area (h). Fuel consumption of the machine was measured using top fill method. Fuel tank was filled before operation and re-filled after operation. Here, fuel consumption was equivalent to re-filled quantity of fuel.

$$
\text { Fuel consumption, } 1 \mathrm{ha}^{-1}=\frac{\text { Re-filled quantity of fuel in Litre }}{\text { Area covered in ha }}
$$

\subsection{1 $\mathrm{CO}_{2}$ emission}

Diesel content carbon and during burning that carbon is combined with oxygen and makes $\mathrm{CO}_{2}$. Thus, tillage operation emits a large amount of $\mathrm{CO}_{2}$ in atmosphere. Tillage machinery discharge $2.640 \mathrm{~kg} \mathrm{CO}_{2}$ from utilization of one-litre diesel during tillage operation and that is a vital source of Green House Gases (GHG) [31]. So, $\mathrm{CO}_{2}$ emission per ha was calculated using following equation.

$$
\text { CO2 emission }\left(\mathrm{kg} \mathrm{ha}^{-1}\right)=2.640 \times \text { Fuel consumption }\left(\mathrm{l} \mathrm{ha}^{-1}\right)
$$

\subsubsection{Cost for machine operation}

Total cost of machine operation at farm level are fixed cost and variable cost. Components of fixed cost included depreciation, bank interest rate (\%), shelter, taxes and insurance where components of variable cost included yearly repair and maintenance cost, fuel \& oil cost, operator charge and miscellaneous expenses. Fixed cost per year $\left(\mathrm{FC}_{y r}\right)$ was calculated using equation (6) [32] and fixed cost per hectare ( $\left.\mathrm{FC}_{\mathrm{ha}}\right)$ was calculated using equations (7) and (8).

$$
F C_{y r}=D+I+S T I
$$


where, $\mathrm{FC}_{\mathrm{yr}}=$ total fixed cost per year in $\mathrm{US} \$ \mathrm{yr}^{-1} ; D=$ depreciation, US $\$ \mathrm{yr}^{-1} ; \mathrm{I}=$ interest on investment (bank interest rate on agricultural loans), US\$ $\mathrm{yr}^{-1}$; STI $=$ shelter, tax and insurance US\$ $\mathrm{yr}^{-1}$;

$$
\text { Fixed cost per hectare, } \mathrm{FC}_{\mathrm{ha}}=\frac{F C \mathrm{yr}}{A_{y r}}
$$

where, Ayr $=$ Area covered per year $=\frac{\text { Annual operating time }}{\text { Time required to prepare } 1 \text { ha }}$

Area covered per year for four-wheel tractor $=$ Area covered per year for disc plough equal area covered per year for disc harrow $=$ area covered per year for tractor trencher. Because one tractor was considered for disc ploughing, harrowing and tractor trenching. Annual operating time of machine operation was assumed as $960 \mathrm{~h}$ considering $8 \mathrm{~h}$ for 120 days because the plantation of sugarcane in Bangladesh starts from middle October and ends in middle February. Depreciation was calculated following sinking-fund depreciation method and using equation (9) [32].

$$
\mathrm{D}=\left[(\mathrm{P}-\mathrm{S})\left\{\frac{(1+i)^{L}-(1+i)^{n}}{(1+i)^{L}-1}\right\}+S\right]-\left[(\mathrm{P}-\mathrm{S})\left\{\frac{(1+i)^{L}-(1+i)^{n+1}}{(1+i)^{L}-1}\right\}+S\right.
$$

where, $\mathrm{D}=$ depreciation, US\$ $\mathrm{yr}^{-1} ; \mathrm{P}=$ purchase price (Table 1$)$, US\$; $\mathrm{S}=$ salvage value $(10 \%$ of $\mathrm{P})$, US\$; $\mathrm{L}=$ Effective machine life, $\mathrm{yr}$ (Table 1); $\mathrm{n}=$ age of machine at beginning, $\mathrm{yr} ; \mathrm{i}=$ annual interest rate, decimal. For a new machine $\mathrm{n}=0$ and uniform depreciation per year equation (9) becomes as equation (10).

$$
\mathrm{D}=(\mathrm{P}-\mathrm{S})\left\{\frac{i}{(1+i)^{L}-1}\right\}
$$

Interest on investment (I) is the charge due to interest of the money that is used as capital investment for the machine either the money was borrowed or not. The interest rate was assumed as $14 \%$ and equation (11) was used for the calculation of interest on invest [32].

$$
\mathrm{I}=\frac{P+S}{2} \times i
$$

Taxes, Shelter and Insurance (STI) was considered as 2.5\% of purchase price of machine [32] and express as equation (12).

$$
S T I=2.5 \% \text { of } P
$$

\subsubsection{Variable cost}

Variable costs are expenses that occur due to operation of the machine. It depends on different input costs for operation and time required (hr) for each field operations. Operator/labour charge was considered as the 
labor rate in US\$ per day. The fuel and oil costs were determined by multiplying their respective prices with their respective consumption rate. Equation (13) was used to calculate variable cost [32].

Variable Cost $\left(\mathrm{US} \$ \mathrm{ha}^{-1}\right), \mathrm{VC}=\mathrm{Lb}+\mathrm{F}+\mathrm{O} \& L+R \& M+M c$

Where, $\mathrm{L}_{\mathrm{b}}=$ Operator $\&$ labor cost, US $\$ \mathrm{ha}^{-1}, \mathrm{~F}=$ Fuel cost, US $\$ \mathrm{ha}^{-1}=$ Fuel consumption $\left(1 \mathrm{ha}^{-1}\right) \times$ Fuel price (US\$/1), O \& L = Oil \& lubrication cost $=15 \%$ of fuel cost, R \& M = Repair and maintenance cost per year $(3.5 \%$ of $\mathrm{P}) / A_{h a}, \mathrm{M}_{\mathrm{c}}=$ Miscellaneous cost $\left(\mathrm{US} \$ \mathrm{ha}^{-1}\right)$ was not considered in this cost calculation.

Total operating costs are the expenses required to operate and maintain a machine during its useful life [33]. Total costs of land preparation in US\$ per ha was calculated using equation (14) as summation of fixed costs (US\$ ha-1) and variable costs (US\$ ha' $\left.{ }^{-1}\right)$.

Total operating costs $\left(\mathrm{US} \$ \mathrm{ha}^{-1}\right), \mathrm{TC}=\mathrm{FC}+\mathrm{VC}$

\section{Result and discussions}

\subsection{Specification of developed conservation tillage trencher}

Developed CTT was attached with 2WT (Figure 8) for preparing sugarcane farmland at different conservation tillage method. Overall specifications of the implement is presented in Table 2. The CTT was $600 \mathrm{~mm}$ long, $1130 \mathrm{~mm}$ width and $440 \mathrm{~mm}$ high (Table 2). The width of the CTT was $1130 \mathrm{~mm}$ since tool bar frame was extended for maintaining $1 \mathrm{~m}$ maximum distance between two trenches. Speed of the rotary shaft was $250 \mathrm{rpm}$, which was similar to the rotational speed of the conventional tiller. Blades on modified rotary shaft were readjusted able and removable, where 12 numbers of L type blades containing 6 blades at each end of rotor for BT and 6 numbers of L type blades at middle of rotor for ST were attached with modified rotary shaft (Table 2). No blade was used for ZT (Table 2) where only two chisel ploughs were used to make trench for sugarcane planting. Total number of blades used for each tillage method were reduced significantly as well as rearranged (Figure 2 (a and b)) that ensure favorable soil condition for seedbed preparation. Conservation tillage can be done successfully through modification of rotary shaft by rearranging and reducing rotary blades $[21,34,35]$. During BT, bed shaper was used for making bed cum trench and two chisel ploughs of developed CTT were for increasing depth of trench. CTT needs to rearrange different functional components for using different options. Local manufacturers could easily fabricate the two-wheel tractor operated CTT using locally available MS materials. Weight of developed CTT was $50 \mathrm{~kg}$ (Table 2) where the weight of Bangladesh Agricultural Research Institute (BARI) developed CA machine named BARI seeder for planting cereal and pulse seed was $136 \mathrm{~kg}$ [36]. Our developed CTT implement is less weight which is preferable to operate by single user. Fabrication cost of 
CTT was US\$ 295 without two-wheel tractor and US\$1705 including with $9 \mathrm{~kW}$ two-wheel tractor (Table 2). Price of CTT is much lower than BARI seeder as US\$2375 including with $9 \mathrm{~kW}$ Power tiller [36]. Therefore, it is affordable for small-scale farmers of south Asia countries like Bangladesh.

\subsection{Operating performance of the machine}

Developed 2-wheel tractor operated CTT could prepare land for sugarcane plantation through a single pass and was capable to choose some conservation tillage options as i) bed cum trenching with minimum-tillage (Figure 1(c)), ii) zero-tillage trenching (ZT) (Figure 1(d)) and iii) strip tillage (Figure 1(e)) by operating at different tillage mode whereas conventional tillage (Figure 1(a and b)) required multiple activities.

Single pass of this machine made a pair of trench at a distance of $0.6 \mathrm{~m}$ during BT (Table 3 ). But, optimum row-to-row distance of sugarcane plantation in Bangladesh is about 0.9 to $1 \mathrm{~m}$ [37]. However, operator can control distance between two pairs of trench easily according to requirement during BT. Hence average row distance is maintained as optimum by increasing distance between two pairs of rows that ensure optimum plant population. Thus, effective width becomes $1.8 \mathrm{~m}$ through maintaining $1.2 \mathrm{~m}$ distance between two pairs of rows. Moreover, this type of row adjustment has a positive impact for intercropping in sugarcane farming without any yield penalty of sugarcane [37-40]. The CTT also made a pair of trench through a single pass during zero-tillage trenching but distance between two trenches can be up to $1 \mathrm{~m}$ (Table 3). Considering trench to trench distance as $0.9 \mathrm{~m}$ effective width becomes $1.8 \mathrm{~m}$ during ZT. During strip tillage, a single pass could make only one row and row-to-row distance could maintain according to requirement. So, effective width could considered as $0.9 \mathrm{~m}$ during strip tillage. Sugarcane farmers of Bangladesh maintain this distance to take their satisfactory yield [36, 41].

Forward speed of developed CTT was different for different type of tillage as $1.1 \mathrm{~km} / \mathrm{hr}$ for BT, $0.9 \mathrm{~km} / \mathrm{hr}$ for ZT and $1.9 \mathrm{~km} / \mathrm{hr}$ for ST (Table 3). Speed of CTT was highest during ST because chisel plough was not used for ST. On the other hand, lowest speed was found during ZT because two chisel ploughs were used and no rotary blade was used. Resistance of soil on chisel plough works against forward speed and force acting on rotary blades helps to increase forward speed of CTT. Besides that effective field capacity of the CTT for different types of tillages were found $0.14 \mathrm{ha} \mathrm{h}^{-1}, 0.12 \mathrm{ha} \mathrm{h}^{-1}$ and $0.14 \mathrm{ha} \mathrm{h}^{-1}$ for bed cum trencher, zero tillage trencher and strip tillage, respectively (Table 3). Effective field capacity varies on soil conditions, field size and shape as well as system limitations [32]. Effective field capacity of BARI developed CA machine named BARI seeder was found 0.098 for strip tillage and 0.099 for shallow tillage [36]. Lower weight of developed CTT may responsible for improve machine maneuverability especially 
that can save machine-turning time at the end of field. CTT was required 8-9 seconds for each turn (Table 3). Effective field capacity of a machine directly depends on turning time [32].

Depth and top width of developed trench during bed cum trenching and zero tillage trenching were nearly same, and the values are 120-150 $\mathrm{mm}$ and 80-100 mm, respectively (Table 3). Depth and width of tillage portion during strip tillage were about $100 \mathrm{~mm}$ and $60-80 \mathrm{~mm}$, respectively (Table 3 ). All these tillage operations were suitable for sugarcane plantation considering depth of tillage since sugarcane plantation at a depth of $100 \mathrm{~mm}$ is enough for optimum yield and cane quality [28]. This type of conservation tillage provides benefits of tillage for seed bed preparation as well as gain benefits of no-tillage by avoiding tillage between two rows $[42,43]$.

\subsection{Resource consumption for sugarcane land preparation}

SFP was the most time-consuming tillage method that required 41 hours per hectares when 10 labour worked at a time for manual trenching (Table 4). Time will increase when labour number decrease for manual trenching and time decrease if labour number increase. LFP required only 11.3 hours which was the time required for disc ploughing, harrowing as well as trenching (Table 4). Land preparation using developed conservation tillage implement required only $7.14 \mathrm{~h} / \mathrm{ha}, 8.33 \mathrm{~h} / \mathrm{ha}$ and $7.14 \mathrm{~h} / \mathrm{ha}$ for BT, ZT and ST, respectively (Table 4). Therefore, different conservation tillage as BT, ZT and ST all are time saving tillage method that saves about $80 \%$ time than SFP and $26-37 \%$ than LFP. Thus, use of developed conservation tillage trencher can facilitates timeliness of plantation through saving time of land preparation. Conservation tillage increases yield through ensuring early plantation by reducing the time required for land preparation $[1,44]$.

SFP is the most labour expensive (185 labour h/ha) followed by LFP (11.3 labour-h/ha), ZT (8.33 labour$\mathrm{h} / \mathrm{ha}$ ) where BT and ST are the most labour saving tillage method that requires only 7.14 labour-h/ha) for each (Table 4). So, conservation tillage methods (BT, ST and ZT) saved about $96 \%$ labour than SFP and 26-36\% labour than LFP. In contrast, introduction of farm machinery and conservation tillage can save farm labor requirements [45], and the saved labor shifted from agriculture to more specialized rural and urban jobs, as well as to the new jobs and opportunities created.

LFP required highest amount of fuel to prepare land for sugarcane plantation and the amount was about 65 1/ha followed by SFP (25 1/ha), ZT (10 1/ha), BT (8 1/ha) and ST (7 1/ha) (Table 4). Thus, conservation tillage saved about $85-89 \%$ fuel than LFP and $60-72 \%$ than SFP. Earlier it was also recorded that conservation tillage reduces diesel fuel consumption significantly and that could be reduced fuel consumption more than $80 \%$ comparing with conventional tillage practices [45]. It was estimated that $127 \%$ 
of diesel fuel could save through conservation tillage in India [46]. Therefore, conservation tillage as well as use of conservation tillage implement is appreciable for sustainable cultivation of sugarcane in limitedresource areas $[1,47]$. Therefore, conservation tillage as BT, ST and ZT saves natural resources (fuel, labour and time) significantly than conventional tillage (SFP and LFP).

\subsection{1 $\mathrm{CO}_{2}$ emission}

Highest amount of $\mathrm{CO}_{2}$ emission was found from LFP (172 kg/ha) and lowest was only $18 \mathrm{~kg} / \mathrm{ha}$ from ST as shown in Figure 9. $\mathrm{CO}_{2}$ emission from SFP, BT and ZT were $66 \mathrm{~kg} / \mathrm{ha}, 21 \mathrm{~kg} / \mathrm{ha}$ and $26 \mathrm{~kg} / \mathrm{ha}$, respectively (Figure 9). Use of CTT in conservation tillage reduced mechanical works and fuel consumption, and reduces $\mathrm{CO}_{2}$ emission. Generally, diesel fuel is the source of energy for mechanical tillage and after burning that produce $\mathrm{CO}_{2}$ and emits to atmosphere as exhaust gas of engine. Thus, diesel is an important source of Green House Gases (GHG) [31]. However, it may vary slightly depending on the engine condition. So, higher amount of fuel required for conventional tillage is responsible for higher amount of $\mathrm{CO}_{2}$ emission. Releases greenhouse gasses due to the burning of fossil fuels have significant impact on global climate changes patterns [48]. Conservation tillage in sugarcane farming reduced $\mathrm{CO}_{2}$ emission to atmosphere in comparing with SFP and LFP by $60-72 \%$ and $85-89 \%$, respectively. Conservation tillage saves fuel and reduces $\mathrm{CO}_{2}$ emission [36]. Therefore, adoption of CTT can lead to sustainable farming of sugarcane since that reduces GHS especially $\mathrm{CO}_{2}$ emission to atmosphere and thus contributes to slow down the climate change process.

\subsection{Economic Performance of CTT}

The economic analysis of developed CTT was done by considering fixed cost, variable cost and total cost of land preparation for sugarcane plantation under different tillage methods (Table 5). Fixed cost to prepare sugarcane land for plantation was highest for LFP (49.6 US \$ ha- $\left.{ }^{-1}\right)$ followed by SFP (4.5 US \$ ha $\left.{ }^{-1}\right)$ as well as Conservation tillage using CTT as ZT (1.8 US \$ ha $\left.{ }^{-1}\right)$, and lowest for BT and ST (1.6 US \$ ha $\left.{ }^{-1}\right)$. It was due to high investment for LFP. But SFP requires highest variable cost (171.3 US $\left.\$ \mathrm{ha}^{-1}\right)$ followed by LFP (81.7 US \$ ha- ${ }^{-1}$ ), ZT (16.0 US \$ ha $\left.\mathrm{a}^{-1}\right)$, BT (13.2 US \$ ha- ${ }^{-1}$ ) and ST (12.3 US \$ ha $\left.{ }^{-1}\right)$. Manual trenching was responsible for highest variable cost than SFP, and high fuel consumption was responsible for second highest variable cost of LFP. Total cost of land preparation was highest for SFP (175.8 US \$ ha ${ }^{-1}$ ) followed by LFP (131.3 US $\left.\$ \mathrm{ha}^{-1}\right)$, ZT (17.8 US $\left.\$ \mathrm{ha}^{-1}\right)$, BT (14.8 US $\left.\$ \mathrm{ha}^{-1}\right)$ and ST (13.9 US $\left.\$ \mathrm{ha}^{-1}\right)$. Thus, cost savings by any conservation tillage for sugarcane farming using CTT was $90 \%$ comparing with SFP and above $86 \%$ comparing with LFP. Conservation tillage saves large amount of costs than conventional tillage [20] and found as economical land preparation method for sugarcane cultivation [49]. Conservation tillage for sugarcane plantation is cost saving land preparation system since it requires less labour and fuel [1]. 
Conservation tillage also increases net economic return as it reduces cost of cultivation [16]. Therefore, it can be concluded that, developed CTT is economically suitable for small-scale sugarcane farmers to adopt conservation tillage considering initial investment and low cost of production.

\section{Conclusions}

In this study, an efficient conservation tillage trencher is modified which offer a resource saving and climate smart land preparation method in sugarcane production system in Bangladesh. Developed conservation tillage implement is capable to make bed-cum trench, zero tillage trench and strip tillage options for sugarcane plantation which ensures minimum tillage and saves land preparation time. Using this CTT implement in sugarcane farming saved fuel cost by $60-89 \%$, field labour by $26-96 \%$, and times by $26-80 \%$ over the conventional tillage methods. CTT implement also reduced $\mathrm{CO}_{2}$ emission as $60-72 \%$ and $85-89 \%$ in comparing with SFP and LFP, respectively. Use of developed conservation tillage implement for sugarcane land preparation saves $90 \%$ and $86 \%$ operating cost compared to SFP and LFP, respectively. Therefore, considering the lower energy consumption and higher economic benefits, developed conservation tillage implement has a great potentiality in small-scale sugarcane farming system in Bangladesh. Furthermore, quality control of implement during the manufacturing and unskilled operator training are major challenges for successful commercialization of this implement for small-scale sugarcane farmers of developing countries likes Bangladesh.

\section{Acknowledgements}

The first author is very much grateful and would like to acknowledge to the National Agricultural Technology Project (NATP); Phase-II, Bangladesh Agricultural Research Council (BARC) and Bangladesh Sugarcrop Research Institute (BSRI) for provided financial support to conduct the research during the doctoral program. The authors also gratefully acknowledge contribution of Quazi Srasthatya Prottasha, Artist-Cum-Illustrator, BSRI for his cordial cooperation.

\section{Author Contributions}

Conceptualization, methodology and writing — original draft preparation: S.S.T. M.A.A; writing — review and editing: M.A.A., M.A.K., M.S.H; reviewing, funding acquisition and supervision: M.A.A., M.A.H. and M.R.A. All authors have read and agreed to the published version of the manuscript.

\section{Funding}

This research received no external funding.

\section{Institutional Review Board Statement}


Not applicable.

\section{Informed Consent Statement}

Not applicable.

\section{Data Availability Statement}

Data sharing not applicable.

\section{Conflicts of Interest}

The authors declare no conflict of interest.

\section{References}

1. Tabriz, S.S.; Kader, M.A.; Rokonuzzaman, M.; Hossen, M.S.; Awal, M.A. Prospects and challenges of conservation agriculture in Bangladesh for sustainable sugarcane cultivation. Environ. Dev. Sustain. 2021. https://doi.org/10.1007/s10668-021-01330-2

2. BSRI. Bangladesh Sugarcrop Research Institute, Ishurdi, Pabna, Bangladesh. Access on: www.bsri.gov.bd 13 May 2020.

3. Rahman, M.S.; Khatun, S.; Rahman, M.K. Sugarcane and sugar industry in Bangladesh: An overview. Sugar Tech 2016, 18(6), 627-635.

4. Boone, F.R. Weather and other environmental factors influencing crop responses to tillage and traffic. Soil Till. Res. 1988, 11(3-4), 283-324.

5. Hobbs, P.R.; Govaerts, B. How conservation agriculture can contribute to buffering climate change. In Climate Change and Crop Production; Reynolds, M.P., Ed.; CAB International: Wallingford, UK, 2010; pp. 177-199.

6. Dharmawardene, M.W.N. Trends in farm mechanization by sugarcane small land holders in Sri Lanka. Sugar Tech 2006, 8, 16-22. https://doi.org/10.1007/BF02943736

7. Islam, A.K.M.S.; Hossain, M.M.; Saleque, M.A.; Rahman, M.A.; Karmakar, B.; Haque, M.E. Effect of minimum tillage on soil properties, crop growth and yield of aman rice in drought prone northwest Bangladesh. Bangladesh Agron. J. 2012, 15(1), 43-51.

8. Gathala, M.K.; Kumar, V.; Sharma, P.C.; Saharawat, Y.S.; Jat, H.S.; Singh, M.; Kumar, A.; Jat, M.L.; Humphreys, E.; Sharma, D.K.; Sharma, S.; Ladha, J.K. Optimizing intensive cereal-based cropping systems addressing current and future drivers of agricultural change in the northwestern Indo-Gangetic Plains of India. Agriculture, Ecosystems and Environ. 2013, 177, 85-97.

9. Kumar, V.; Saharawat, Y.S.; Gathala, M.K.; Jat, A.S.; Singh, S.K.; Chaudhary, N.; Jat, M.L. Effect of 
different tillage and seeding methods on energy use efficiency and productivity of wheat in the IndoGangetic Plains. Field Crops Res. 2013, 142, 1-8.

10. Hossain, S.M.I.; Eusufzai, S.U.K.; Rahman, M.A. Development and Evaluation of a Power Tiller Mounted Trencher for Sugarcane. Bangladesh J. Sugarcane 2005, 24(27), 112-120.

11. Hossain, S.M.I.; Zaman, M.A; Eusufzai, S.U.K.; Abdullah. M. Status and Prospect of Mechanization of Sugarcane Cultivation in Bangladesh. AMA. 1996, 27 (3), 68-72. https://doi.org/10.1002/bbb.1623

12. Rahman, M.A.; Eusufzai, S.U.K.; Siddique, M.A.B.; Amanullah, A.S.M.; Tabriz, S.S. An overview of present status and prospect of mechanization of sugarcane cultivation in Bangladesh. J. Agricultural Eng. 2009, 37, 7-13.

13. Wood, A.W. Soil degradation and management under intensive sugarcane cultivation in North Queensland. Soil Use and Management 1985, 1(4), 120-124.

14. Tenelli, S.; de Oliveira Bordonal, R.; Barbosa, L.C.; João Carvalho, L. N. Can reduced tillage sustain sugarcane yield and soil carbon if straw is removed? Bioenerg. Res. 2019, 12, 764-777. https://doi.org/10.1007/s12155-019-09996-3

15. Garside, A.L.; Watters, T.S.; Berthelsen, J.E.; Sing, N.J.; Bell, M.J. Comparisons between conventional and alternative sugarcane farming systems which incorporate permanent beds, minimum tillage, controlled traffic and legume fallow. Proc. Aust. Soc. Sugar Cane Technol. 2004, 26.

16. Jat, M.L.; Chakraborty, D.; Ladha, J.K.; Rana, D.S.; Gathala, M.K.; McDonald, A.; Gerard, B. Conservation agriculture for sustainable intensification in South Asia. Nat. Sustain. 2020, 3, 336-343.

17. Segnini, A.; Carvalho, J.L.N.; Bolonhezi, D.; Milori, D.M.B.P.; Silva, W.T.L.; Simões, M.L.; Cantarella, H.; Maria, I.C.; MartinNeto, L. Carbon stock and humification index of organic matter affected by sugarcane straw and soil management. Sci. Agric. 2013, 70, 321326. https://doi.org/10.1590/S0103-90162013000500006

18. Braunack, M.V.; McGarry, D.C.; Crees, L.R.; Halpin, N. Strategic tillage for planting sugarcane. Proc. Aust. Soc. Sugar Cane Technol. 1999, 21, 101-107.

19. Bell, M.J.; Halpin, N.V.; Orange, D.N.; Haines., M. Effect of compaction and trash blanketing on rainfall infiltration in sugarcane soils. Proc. Aust. Soc. Sugar Cane Technol. 2001, 23, 161-167.

20. Grange, I.; Prammanee, P.; Prasertsak, P. Comparative analysis of different tillage systems used in sugarcane (Thailand). AFBM J. 2005, 2 (1), 46-50.

21. Hoque, M.A.; Gathala, M.K.; Hossain, M.M.; Ziauddin, A.T.M.; Krupnik, T.J. Modified strip tillage blades for two-wheel tractor seed drills improves maize crop establishment under conservation agriculture. Dev. Eng. 2021, 6, p.100061.

22. Hossain, M.I.; Sarker, M.J.U.; Haque, M.A. Status of conservation agriculture based tillage technology for crop production in Bangladesh. Bangladesh J. Agril. Res. 2015, 40(2), 235-248. 
23. Raheman, H.; Sahu, R.K.; Design of tractor operated rotary cultivator- a computer simulation. $A M A$. 2006, 37(3), 27-31.

24. Lal, R. No-till farming: Soil and water conservation and management in the humid and sub-humid tropics; IITA Monograph No. 2: Ibadan, Nigeria, 1983; p.64.

25. Mc Kyes, E.; Ali, O.S. The cutting of soil by narrow blades. J. Terramech. 1977, 14, 43-58.

26. Swick, W.C.; Perumpral, J.V. A model for predicting soil-tool interaction. J. Terramech. 1988, 25, 43-56.

27. Tong, J.; Moayad, B.Z. Effects of rake angle of chisel plough on soil cutting factors and power requirements: A computer simulation. Soil Till. Res. 2006, 88, 55-64.

28. Broadhead, M.D.; Stokes, E.; Freeman, K.C. Sugarcane Depth-of-Planting Experiments in Alabama and Mississippi. Agron. J. 1963, 55(5), 419-420.

29. Hunt, D.; Wilson, D. Farm Power and Machinery Management, 11th ed.; Waveland Press, Inc.: Long Grove, Illinois, USA, 2015; pp. 3-28

30. Kepner, R.A.; Bainer, R.; Barger, E.L. Principles of Farm Machinery, 3rd ed.; The AVI Publishing Company, Inc.: Westport, USA, 1978; pp. 25-32.

31. Grace, P.R. Rice-wheat system and climatic change. In Addressing Resource Conservation Issues in Rice-Wheat Systems of Sough Asia: A Resource Book, Rice-Wheat Consortium for the Indo-Gangetic Plains - Intl. Maize and Wheat Impr. Cent.: New Delhi, India, 2003; pp. 63-67.

32. Hunt, D. Farm power and machinery management, 10th ed., Iowa state university press, USA, 2001.

33. White, J.A.; Agee, M.H.; Case K.E. Principles of Engineering Economic Analysis, 3rd ed.; John Wiley \& Sons, Incorporated: London-New York-Melbourne, 1989.

34. Hoque, M.A.; Miah, M.S. Evaluation of different tillage methods to assess BARI inclined plate planter. AgricEngInt: CIGR J. Open 2015, 17 (3), 128-137.

35. Hossain, M.I.; Haque, M.E.; Meisner, C.A.; Sufian, M.A.; Rahman, M.M. Strip tillage planting method for better wheat establishment. J. Sci. Technol. 2005, 3:91-95.

36. Mottalib, M.A.; Hossain, M.A.; Hossain, M.I.; Amin, M.N.; Saha, C.K.; Alam M.M. Enhancing economically and eco-friendly jute production through appropriate conservation agricultural tillage cum seeding methods in the southwestern coastal region of Bangladesh. IJEI. 2019, 8(1), 27-46.

37. Alam, M.J.: Rahman, M.M.; Sohel, M.A.T.; Razzak, M.A.; Roy, H.P.; Islam, S.; Khaiyam, M.O.; Rahman, M.S. Productivity of soybean-mungbean sequential intercropping with paired rows transplanted sugarcane. Bangladesh J. Sugarcane 2015, 36, 59-68. 
38. Roach, B.T. Evaluation of effect of double row planting of sugarcane. Proc. ISSCT, 1977; 4,131-137.

39. Shaheen, M.; Hossain, A.H.M.D.; Gaffer, M.A.; Sadaque, M.A. Row arrangement for Mustard intercropping with sugarcane. Bangladesh J. Sugarcane 1989, 11, 41-46.

40. Hossain, M.I.; Al-Amin, H.M.; Islam, M.S.; Uddin, M.J.; Reza, M.E. Performance of onion seed crop and mungbean sequential intercropping at paired rows planted sugarcane. Bangladesh J. Sugarcane 2016, 37, 93-99.

41. Alam, M.J.; Rahman, M.M.; Razzak, M.A.; Roy. H.P.; Sohel, M.A.T. Performance of onion seed crop and mungbean sequential intercropping at paired rows planted sugarcane. Bangladesh J. Sugarcane 2016, 37, 100-110.

42. Licht, M.A.; Al-Kaisi, M. Strip-tillage effect on seedbed soil temperature and other soil physical properties. Soil Till. Res. 2005, 80, 233-249.

43. Vyn, T.J.; Raimbault, B.A. Long-term effect of five tillage systems on corn response and soil structure. Agron. J. 1993, 85, 1074-1079.

44. Haque, M.E.; Bell, R.W.; Islam, M.A.; Rahman, M.A. Minimum tillage unpuddled transplanting: An alternative crop establishment strategy for rice in conservation agriculture cropping systems, Field Crops Res. 2016, 185, 31-39.

45. Haque, M.E.; Bell, R.W.; Kassam, A.; Mia, M.N.N. Versatile Strip Seed Drill: A 2-Wheel TractorBased Option for Smallholders to Implement Conservation Agriculture in Asia and Africa. Environ. 2016, 3(1), 1-13. https://doi.org/10.3390/environments3010001

46. Erenstein, O.; Farooq, U.; Malik, R.K.; Sharif, M. Adoption and impacts of zero tillage as a resource conserving technology in the irrigated plains of South Asia; International Water Management Institute: Colombo, Sri Lanka. 2007; p.55. (Comparative Assessment of Water Management in Agriculture Research Report 19). doi: http://dx.doi.org/10.3910/2009.374

47. So, H.B.; Kirchhof, G.; Bakker, R.; Smith, G.D. Low input tillage/cropping systems for limited resource areas. Soil Till. Res. 2001, 61, 109-123.

48. Matthes, F.C. Climate change 2007: The physical science basis, impacts, adaptation and vulnerability mitigation of climate change. Int. Politik 2007, 63, 130-132.

49. Moraes, E.R.; Bernardes, R.F.B.; Domingues, L.A.S.; Lana, R.M.Q. Productivity and agronomic characteristics of sugarcane under different tillage systems. Scientific Electronic Archives 2017, 10(1), $75-79$. 